International Journal of Trend in Scientific Research and Development (IJTSRD)

Volume: 3 | Issue: 3 | Mar-Apr 2019 Available Online: www.ijtsrd.com e-ISSN: 2456 - 6470

\title{
Methanol Extract of Unfermented Theobroma Cacao Promotes Normal Lipid Profile of Wistar Rats
}

\author{
Eyuwa Ignatius Agwupuye1, Justin Atiang Beshel2, 3, \\ Assumpta Chioma Anosike1, Lawrence U. Ezeanyika1 \\ 1Department of Biochemistry, 2,3Department of Physiology \\ ${ }^{1}$ Faculty of Biological Sciences, University of Nigeria, Nsukka, Nigeria \\ ${ }^{2}$ Faculty of Basic Medical Sciences, College of Medical Sciences, University of Calabar, Calabar, Nigeria \\ ${ }^{3}$ Kampala International University, Western Campus, Ishaka, Uganda
}

\begin{abstract}
How to cite this paper: Eyuwa Ignatius Agwupuye | Justin Atiang Beshel | Assumpta Chioma Anosike | Lawrence U. Ezeanyika "Methanol Extract of Unfermented Theobroma Cacao Promotes Normal Lipid Profile of Wistar Rats" Published in International Journal of Trend in Scientific Research and Development

(ijtsrd), ISSN: 24566470, Volume-3 | Issue-3, April 2019, pp.190-193, URL: http://www.ijtsrd.co $\mathrm{m} /$ papers/ijtsrd217

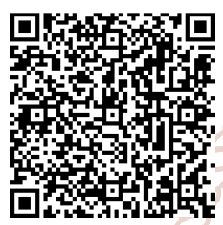
IITSRD21730
\end{abstract} 30.pdf

Copyright (C) 2019 by author(s) and International Journal of Trend in Scientific Research and Development Journal. This is an Open Access article distributed under the terms of the Creative Commons

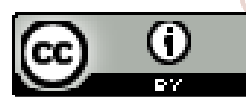
Attribution License (CC BY 4.0) (http://creativecommons.org/licenses/ by $/ 4.0$ )

\section{INTRODUCTION}

Cocoa (Theobroma cacao) belongs to the genus Theobroma, a group of small trees which grow in the Amazon basin and other tropical areas of South and Central Africa (fig. 1). They are classified under the subfamily Sterculioidea of the mallow family Malvaceae. The medicinal value of cocoa plants have assumed a more important dimension in the past few decades owing largely to the discovery that, extracts from cocoa plants contain not only minerals and primary metabolites, but also a diverse array of secondary metabolites with antioxidant potentials (Akinmoladum et al., 2007).

Cocoa bean and its product (cocoa liquor, cocoa powder, and dark chocolate) are food sources rich in phenolic compounds (Arts et al., 1999). The pharmacologically active ingredients of cocoa seeds include amines, alkaloids, fatty acids, polyphenols, magnesium, phenylethylamine, theobromine, caffeine and $\mathrm{N}$-acylethanolamines (Bruinsma and Taren, 1999). The health promoting properties of cocoa beans are attributed to their phenolic compounds, catechins and flavonols (Kelmet al., 2006), which are potent antioxidants that can attenuate inflammatory processes and other disease states.

Cocoa products also contain high levels of biologically active polyphenols that exert both acute and chronic antioxidantassociated health benefits (Kris-Etherton and Keen, 2002). Cocoa and cocoa products have also been shown to suppress the development of atherosclerotic lesions (Kurosawa et al., 2005), decrease platelet function (Murphy et al., 2003), increase dermal blood flow (Neukan, et al., 2007), inhibits the proliferation of human breast cancer cells (Ramljaket al., 2005), possess hypoglycaemic properties and decrease oxidation of LDL cholesterol (Tomaruet al., 2007). Due to its wide consumption, especially in food industries, with attendant increase in cardiovascular disorders, evaluating the effect of Theobroma cacao on lipid profile becomes very necessary. 


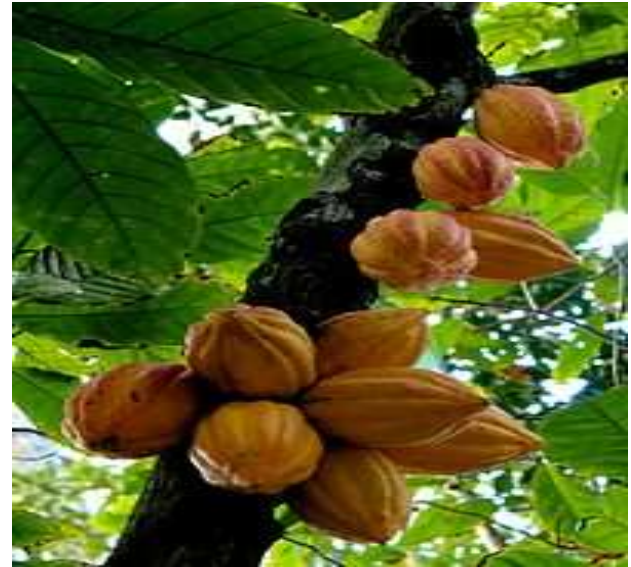

Fig 1: Theobroma cacao tree with mature pods

\section{MATERIALS AND METHODS}

\section{Plant Material}

Unfermented Theobroma Cacao (cocoa beans) was obtained from a farm in Cross River State, Nigeria. The seeds were decoated, ground and sieved into fine powder (cocoa powder). The methanol extract of Theobroma Cacao was obtained by macerating $1500 \mathrm{~g}$ of the cocoa powder in $2000 \mathrm{ml}$ of methanol (BDH Ltd Poole, England) for 24 hours. The suspension was thereafter filtered with Whatman No.1 filter paper. The filtrate was concentrated under reduced pressure and the yield recorded.

\section{Animals}

Twenty-four (24) adult male Wistar rats (140 - 200g) were used for the study. They were divided into 4 groups of 6 rats each. Group 1 served as the normal control placed on normal saline. Groups 2, 3, and 4 were administered $200 \mathrm{mg} / \mathrm{kg}$, $400 \mathrm{mg} / \mathrm{kg}$, and $800 \mathrm{mg} / \mathrm{kg}$ of methanol extract of unfermented Theobroma cacao respectively. Administration was via oral gavage, and lasted for 21 days. Approval was sought and consent granted by the Faculty of Biological Sciences Animal Research Ethics Committee, University of Nigeria, Nsukka, with Approval No: 019BCM20317. The animals were kept in plastic cages and controlled environment $\left(12 \mathrm{~h}\right.$ light/dark cycles at $\left.27 \pm 2^{\circ} \mathrm{C}\right)$ one week for acclimatization before commencement of the study. The rats had free access to normal rat chow and tap water ad libitum.

\section{Estimation of Lipid Profile}

Blood samples of the rats were collected into sterilized centrifuge tubes on day zero, 14, and 21 of the experiment and were immediately spurned at $4000 \mathrm{rpm}$ for 10 minutes. Serum was collected into clean sample bottles for biochemical assays. Lipid profile was evaluated by assessing Total cholesterol (Tc) [Siedel et al., 1983], Triacylglycerides (TAG) [Sullivan et al., 1985], High Density Lipoprotein (HDLc), and Low Density Lipoprotein (LDL-c) [Friedewald et al., 1992]. All analysis was performed using commercially available kits based on the references and Manufacturer's instructions using analyzer.

\section{Statistical Analysis}

The results are presented as mean \pm standard error of the mean. Data were analyzed using GraphPad prism software version 6.00 for Windows (GraphPad Software, San Diego, CA, USA). One-way analysis of variance with Turkey's posttest was performed, and probability level of $p<0.05$ was considered statistically significant.

\section{Results}

Effect of methanol extract of unfermented $T C$ on serum total cholesterol

The mean serum total cholesterol in the control, $200 \mathrm{mg} / \mathrm{kg}$, $400 \mathrm{mg} / \mathrm{kg}$, and $800 \mathrm{mg} / \mathrm{kg}$ of TC extract treated groups was $3.53 \pm 0.12 \mathrm{mmol} / \mathrm{L}, 3.10 \pm 0.06 \mathrm{mmol} / \mathrm{L}, 2.93 \pm 0.07 \mathrm{mmol} / \mathrm{L}$ and $2.57 \pm 0.09 \mathrm{mmol} / \mathrm{L}$ respectively on the $14^{\text {th }}$ day of feeding, and $3.47 \pm 0,03 \mathrm{mmol} / \mathrm{L}, 2.80 \pm 0.12 \mathrm{mmol} / \mathrm{L}, 2.73 \pm$ $0.09 \mathrm{mmol} / \mathrm{L}$, and $2.33 \pm 0.03 \mathrm{mmol} / \mathrm{L}$ respectively after the $21^{\text {st }}$ day of feeding. There was a significant $(\mathrm{p}<0.05)$ decrease serum total cholesterol in the $T C$ treated group when compared with the control group. This is presented in table1.

\section{Effect of methanol extract of unfermented $T C$ on serum} low density lipoprotein (LDL-c)

The LDL-c levels in the control, $200 \mathrm{mg} / \mathrm{kg}, 400 \mathrm{mg} / \mathrm{kg}$ and $800 \mathrm{mg} / \mathrm{kg}$ extract treated groups was $1.60 \pm 0.06 \mathrm{mmol} / \mathrm{L}$, $1.10 \pm 0.57 \mathrm{mmol} / \mathrm{L}, 1.06 \pm 0.06 \mathrm{mmol} / \mathrm{L}$, and $1,13 \pm$ $0.008 \mathrm{mmol} / \mathrm{L}$ respectively on the $14^{\text {th }}$ day of feeding, and $1.53 \pm 0.003 \mathrm{mmol} / \mathrm{L}, \quad 1.20 \pm 0.10 \mathrm{mmol} / \mathrm{L}, 1.10 \pm$ $0.10 \mathrm{mmol} / \mathrm{L}$, and $1.10 \pm 0.06 \mathrm{mmol} / \mathrm{L}$ after the $21^{\text {st }}$ day of the feeding period. The result showed decrease $(p<0.05)$ levels of LDL-c in the TC treated groups compared with the control. This is presented in table 2 .

Effect of methanol extract of $T C$ on serum triacylglyceride (TAG) level

The serum triglyceride level in the control, $200 \mathrm{mg} / \mathrm{kg}$, $400 \mathrm{mg} / \mathrm{kg}$, and $800 \mathrm{mg} / \mathrm{kg}$ extract treated groups was $1.27 \pm$ $0,07 \mathrm{mmol} / \mathrm{L}, 1.20 \pm 0.06 \mathrm{mmol} / \mathrm{L}, 1.27 \pm 0.03 \mathrm{mmol} / \mathrm{L}$, and $1.03 \pm 0.09 \mathrm{mmol} / \mathrm{L}$ respectively on the $14^{\text {th }}$ day of feeding, and $1.30 \pm 0.06 \mathrm{mmol} / \mathrm{L}, 1.17 \pm 0.07 \mathrm{mmol} / \mathrm{L}, 0.97 \pm$ $0.09 \mathrm{mmol} / \mathrm{L}$, and $0.77 \pm 0.09 \mathrm{mmol} / \mathrm{L}$ respectively after the $21^{\text {st }}$ day of the feeding period. Significant reductions $(p \leq 0.05)$ in triacylglycerol (TAG) were only observed in the group administered 400 and $600 \mathrm{mg} / \mathrm{kg}$ of the extract after 21 days. This is presented in table 3.

\section{Effect of methanol extract of $T C$ on serum high density lipoprotein}

HDL-c level in the control, $200 \mathrm{mg} / \mathrm{kg}, 400 \mathrm{mg} / \mathrm{kg}$, and $800 \mathrm{mg} / \mathrm{kg}$ extract treated groups after the $14^{\text {th }}$ and $21^{\text {st }}$ days of feeding was $1.33 \pm 0.09 \mathrm{mmol} / \mathrm{L}, 1.63 \pm 0.13 \mathrm{mmol} / \mathrm{L}, 1.67$ $\pm 0.15 \mathrm{mmol} / \mathrm{L}, 1.83 \pm 0.07 \mathrm{mmol} / \mathrm{L}$, and $1.47 \pm 0.07 \mathrm{mmol} / \mathrm{L}$, $1.87 \pm 0.07 \mathrm{mmol} / \mathrm{L}, 2.07 \pm 0.03 \mathrm{mmol} / \mathrm{L}$, and $1.83 \pm$ $0.19 \mathrm{mmol} / \mathrm{L}$ respectively. The result showed a significant $(\mathrm{p}<0.05)$ increase level of HDL-c in the TC treated groups compared with the control. This is presented in table 4.

Table 1: Effect of methanol extract of unfermented Theobroma cacao on total cholesterol concentration (mmol/L) of Wistar rats

\begin{tabular}{|c|c|c|c|c|}
\hline Days & Control & $\mathbf{2 0 0} \mathbf{m g} / \mathbf{k g} \mathbf{b} . \mathbf{w}$ & $\mathbf{4 0 0} \mathbf{m g} / \mathbf{k g ~ b . w}$ & $\mathbf{8 0 0} \mathbf{m g} / \mathbf{k g} \mathbf{b} . \mathbf{w}$ \\
\hline Day 0 & $3.40 \pm 0.06_{\mathrm{a}}$ & $3.30 \pm 0.06_{\mathrm{a}}$ & $3.40 \pm 0.12_{\mathrm{a}}$ & $3.40 \pm 0.06_{\mathrm{a}}$ \\
\hline Day 14 & $3.53 \pm 0.12_{\mathrm{a}}$ & $3.10 \pm 0.06_{\mathrm{b}}$ & $2.93 \pm 0.07_{\mathrm{b}}$ & $2.57 \pm 0.09_{\mathrm{b}}$ \\
\hline Day 21 & $3.47 \pm 0.03_{\mathrm{a}}$ & $2.80 \pm 0.12_{\mathrm{b}}$ & $2.73 \pm 0.09_{\mathrm{b}}$ & $2.33 \pm 0.03_{\mathrm{b}}$ \\
\hline
\end{tabular}

Means with different lower case subscripts $(\mathrm{a}, \mathrm{b}, \mathrm{c})$ between and across groups are significantly different at $\mathrm{P}<0.05$. 
International Journal of Trend in Scientific Research and Development (IJTSRD) @ www.ijtsrd.com eISSN: 2456-6470

Table 2: Effect of methanol extract of unfermented Theobroma cacao on LDL-c (mmol/L) concentration of Wistar rats

\begin{tabular}{|c|c|c|c|c|}
\hline Days & Control & $200 \mathrm{mg} / \mathrm{kg} \mathrm{b} \cdot \mathrm{w}$ & $400 \mathrm{mg} / \mathrm{kg} \mathrm{b.w}$ & $800 \mathrm{mg} / \mathrm{kg} \mathrm{b.w}$ \\
\hline Day 0 & $1.67 \pm 0.09$ & $1.47 \pm 0.13$ & $1.60 \pm 0.12$ & $1.60 \pm 0.06$ \\
\hline Day 14 & $1.60 \pm 0.06_{\mathrm{a}}$ & $1.10 \pm 0.57_{\mathrm{b}}$ & $1.06 \pm 0.06_{\mathrm{b}}$ & $1.13 \pm 0.08_{\mathrm{b}}$ \\
\hline Day 21 & $1.53 \pm 0.03_{\mathrm{a}}$ & $1.20 \pm 0.10_{\mathrm{b}}$ & $1.10 \pm 0.10_{\mathrm{b}}$ & $1.10 \pm 0.06_{\mathrm{b}}$ \\
\hline
\end{tabular}

Means with different lower case subscripts $(\mathrm{a}, \mathrm{b}, \mathrm{c})$ between and across groups are significantly different at $\mathrm{P}<0.05$.

Table 3: Effect of methanol extract of unfermented Theobroma cacao on TAG (mmol/L) concentration of Wistar rats

\begin{tabular}{|c|c|c|c|c|}
\hline Days & Control & $200 \mathrm{mg} / \mathrm{kg} \mathrm{b.w}$ & $400 \mathrm{mg} / \mathrm{kg} \mathrm{b.w}$ & $800 \mathrm{mg} / \mathrm{kg} \mathrm{b.w}$ \\
\hline Day 0 & $1.30 \pm 0.06$ & $1.47 \pm 0.09$ & $1.43 \pm 0.03$ & $1.40 \pm 0.06$ \\
\hline Day 14 & $1.27 \pm 0.07 \mathrm{a}$ & $1.20 \pm 0.06_{\mathrm{a}}$ & $1.27 \pm 0.03_{\mathrm{a}}$ & $1.03 \pm 0.09 \mathrm{~b}$ \\
\hline Day 21 & $1.30 \pm 0.06_{\mathrm{a}}$ & $1.17 \pm 0.07 \mathrm{a}$ & $0.97 \pm 0.099_{b}$ & $0.77 \pm 0.099_{b}$ \\
\hline
\end{tabular}

Means with different lower case subscripts (a, b, c) between and across groups are significantly different at $\mathrm{P}<0.05$.

Table 4: Effect of methanol extract of unfermented Theobroma cacao on HDL-c (mmol/L) concentration of Wistar rats

\begin{tabular}{|c|c|c|c|c|}
\hline Days & Control & $200 \mathrm{mg} / \mathrm{kg} \mathrm{b.w}$ & $400 \mathrm{mg} / \mathrm{kg} \mathrm{b} . \mathrm{w}$ & $600 \mathrm{mg} / \mathrm{kg} \mathrm{b.w}$ \\
\hline Day 0 & $1.17 \pm 0.03$ & $1.27 \pm 0.03$ & $1.20 \pm 0.06$ & $1.23 \pm 0.07$ \\
\hline Day 14 & $1.33 \pm 0.09$ & $1.63 \pm 0.13_{\mathrm{a}}$ & $1.67 \pm 015_{\mathrm{a}}$ & $1.83 \pm 0.07_{\mathrm{b}}$ \\
\hline Day 21 & $1.47 \pm 0.07$ & $1.87 \pm 0.07_{\mathrm{b}}$ & $2.07 \pm 0.03_{\mathrm{b}}$ & $1.83 \pm 0.19_{\mathrm{b}}$ \\
\hline
\end{tabular}

Means with different lower case subscripts (a,b,c) across and between groups are significantly different at $\mathrm{P}<0.05$.

\section{Discussion}

The present study investigated the effect of unfermented Theobroma cacao on lipid profile of Wistar rats. Administration of TC resulted in a decrease serum concentration of total cholesterol, low density lipoprotein, triacylglycerides, and an increase in the serum concentration of high density lipoprotein. Abnormal lipid metabolism is a major pathogenic factor for various cardiovascular diseases. Cholesterol for many years is reported to have a direct relationship with cardiovascular prognosis. An increase by $1 \%$ in total cholesterol, results in 2-3\% increase in coronary heart disease (Carlson, Bottiger and Ahfeldt, 1979). Recent studies have shown that total cholesterol increase by $10 \%$ results in coronary-related mortality risk of about $38 \%$ (Law, Wald and Thompson, 1994). LDL on the other hand, is emphasized to be highly implicated in coronary heart disease (ILIB, 2003) and forms a discriminating criterion for cardiovascular risk.

Reports also showcase a relationship between LDHcholesterol and triglycerides, indicating that in men, there is a $13 \%$ increase in the risk of cardiovascular disease, while women have a $37 \%$ increase risk, all resulting from increased levels of triglycerides (Criqui, et al., 1993; Hokanson and Austin, 1996; Assman, Schulte and Eckardstein, 1996).

On the contrary, HDL-cholesterol has an inverse relationship with the risk of coronary heart disease. There is a $2-3 \%$ decrease in the risk of cardiovascular disease for every $1 \mathrm{mg} / \mathrm{dl}$ elevation of HDL-Cholesterol (Gordon et al., 1989). HDL-cholesterol is involved in cholesterol reversal transport, possesses anti-inflammatory capacity and protects against LDL-cholesterol oxidation (Ansell et al., 2004). When the levels of HDL-cholesterol are low, the risk of cardiovascular diseases becomes prominent (Cui, et al., 2001).

The ability of $T C$ to promote normal lipid profile could be due to the presence of flavonoids and polyphenols known to have antioxidant and anti-inflammatory properties (Kelmet al., 2006).

\section{CONCLUSION}

Our study suggests that Theobroma cacao promotes normal lipid profile. This is due to its ability to raise the serum concentrations of HDL-c, with a consequent decrease in the levels of LDL-C, TC, and TAG. This study therefore provides a basis for the use of TC as an alternative in the prevention, management, or control of dyslipidemia.

\section{REFERENCES}

[1] Akinmoladun A. C., Ibukun E. O., Afor E., Akinrinlola B. L., Onibon T. R., Akinboboye, A. O., Obuotor, E. M. and Farombi, E.O. (2007). Chemical constituent and antioxidant activity of Alstoniaboonei. African Journal of Biotechnology, 6: (10)1197-1201.

[2] Ansell, B.J.; Navab, M.; Watson, K.E. (2004). Antiinflamatory properties of HDL. Reviews in Endocrine and Metabolic Disorders. 5:351-358.

[3] Arts, I.C., Hollman P.C. and Kromhout, D. (1999). Chocolate as a source of tea flavonoids. Lancet, 354 (9177): 488-492.

[4] Assman, G.; Schulte, H.; von Eckardstein, A. (1996). Hypertriglyceridemia and elevated lipoprotein (a) are risk factors for major coronary events in middle-aged men. American Journal of Cardiology, 77: 11791184.

[5] Bruinsma K. and Taren D.L. (1999). Chocolate: Food and drug. Journal of American Diet Association, 99(10):1249-1256.

[6] Carlson LA, Bottiger LE, Ahfeldt PE. (1979). Risk factors for myocardial infarction in the Stockholm prospective study. A 14-year follow-up focussing on the role of plasma triglycerides and cholesterol. Acta Medica Scandinavia. 206:351-360.

[7] Criqui, M.H.; Heiss, G.; Cohn, R. (1993). Plasma triglyceride level and mortality from coronary heart disease. New England Journal of Medicine. 328:11201125. 
[8] Cui, Y.; Blumenthal, R.S.; Flaws, J.A. (2001). Non-highdensity lipoprotein cholesterol level as a predictor of cardiovascular disease mortality. Archives of Internal Medicine. 161:1413-1419.

[9] Friedwald, W. T., Levy, R. I., Fredrickson, D.S. (1972). Estimation of the concentration of low-density lipoprotein cholesterol in the plasma, without the use of preparative ultracentrifuge. Clinical Chemistry. 18:449-502.

[10] Gordon, D. J.; Probstfield, J. L.; Garrison, R.J. (1989). High-density lipoprotein cholesterol and cardiovascular disease: four prospective american studies. Circulation. 79:8-15.

[11] Hokanson JE, Austin MA. (1996). Plasma triglyceride level is a risk factor for cardiovascular disease independent of high-density lipoprotein cholesterol level: a meta-analysis of population-based prospective studies. Journal of Cardiovascular Risk. 3:213-219.

[12] Kelm M.A., Johnson J.C., Robbins R.J., Hammerstone J.F., and Schmitz, H.H. (2006). High-performance liquid chromatography separation and purification of cacao (Theobroma cacao L.) procyanidins according to degree of polymerization using a diol stationary phase. Journal of Agricultural and Food Chemistry, 54: 15711576.

[13] Kris-Etherton P.M. and Keen C.L. (2002). Evidence that the antioxidant flavonoids in tea and cocoa are beneficial for cardiovascular health. Current Opinion in Lipidology, 13:41-49

[14] Kurosawa T., Itoh F., Nozaki A., Nakano Y., Katsuda S. I., Osakabe N., Tubone H., Kondo, K. and Itakura $\mathrm{H}$. (2005). Suppressive effect of cocoa powder on atherosclerosis in Kurosawa and Kusanagihypercholesterolemic rabbits. Structural survey, 12:20-28.

[15] Murphy K. J., Chronopoulos A. K., Singh I., Francis M. A., Moriarty H., Pike M. J., Turner A. H., Mann N. J., and Sinclair A.J. (2003). Dietary flavanols and procyanidine oligomers from cocoa (Theobroma cacao) inhibit platelet function. American Journal of Clinical Nutrition, 77:1466-1473.

[16] Neukam K., Stahl W., Tronnier H., Sies H., and Heinric U. (2007). Consumption of flavonol-rich cocoa acutely increases microcirculation in human skin. European Journal of Nutrition.46: 53-56.

[17] Ramljak D., Romancyzk L.J., Methney-Barlow L. J., Thompson N., Knezevic V., Galperin M., Ramesh A., and Dickson R. B. (2005). Pentameric procyanidine from Theobroma cacao selectively inhibits growth of human breast cancer cells. Molecular Cancer Therapy, 4: (4)537-546.

[18] Siedel, J., Hagele, E.O., Ziegenhorn, J., and Wahlefield, A. W. (1983). Reagent for the enzymaticdetermination of serum cholesterol with improved lipolytic efficiency, Clinical Chemistry. 20:1075.

[19] Sullivan DR, Kruijswijk Z, West CE, Kohlmeier M, Katan MB (1985). Determination of serum triglycerides byan accurate enzymatic method not affected by free glycerol. Clinical Chemistry. 31(7):1227-8.

[20] Tomaru, M., Takano, H., Osakabe, N., Yasuda, A., Inouse, K.I., Yangisawa, R., Ohwatari, T. and Uematsu, H. (2007). Dietary supplementation with cacao liquor proanthocyanidins prevents elevation of blood glucose levels in diabetic obese mice. Nutrition, 23: 351-355. 